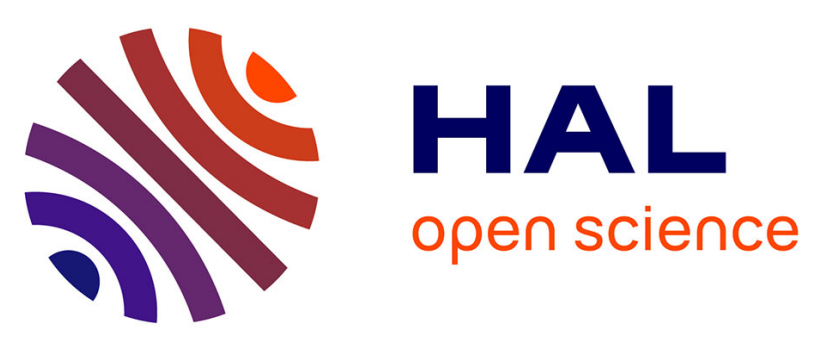

\title{
EFFECT OF HEATING SAMPLES DURING PULSED ELECTRON BEAM ANNEALING ON THE OPEN-CIRCUIT VOLTAGE OF SILICON SOLAR CELLS
}

\author{
A. Laugier, Damien Barbier, M. Doghmane, G. Chemisky
}

\section{To cite this version:}

A. Laugier, Damien Barbier, M. Doghmane, G. Chemisky. EFFECT OF HEATING SAMPLES DURING PULSED ELECTRON BEAM ANNEALING ON THE OPEN-CIRCUIT VOLTAGE OF SILICON SOLAR CELLS. Journal de Physique Colloques, 1983, 44 (C5), pp.C5-369-C5-373. 10.1051/jphyscol:1983554 . jpa-00223140

\author{
HAL Id: jpa-00223140 \\ https://hal.science/jpa-00223140
}

Submitted on 1 Jan 1983

HAL is a multi-disciplinary open access archive for the deposit and dissemination of scientific research documents, whether they are published or not. The documents may come from teaching and research institutions in France or abroad, or from public or private research centers.
L'archive ouverte pluridisciplinaire HAL, est destinée au dépôt et à la diffusion de documents scientifiques de niveau recherche, publiés ou non, émanant des établissements d'enseignement et de recherche français ou étrangers, des laboratoires publics ou privés. 

OPEN-CIRCUIT VOLTAGE OF SILICON SOLAR CELLS

\author{
A. Laugier, D. Barbier, M.S. Doghmane and G. Chemisky \\ Laboratoire de Physique de za Matière (IA 358), Institut National des \\ Sciences Appliquées de Lyon, 20, avenue Albert Einstein, 69621 Villeurbanne \\ Cedex, France
}

\title{
RËSUMÉ
}

On a recherché les causes des faibles tensions en circuit ouvert associées au recuit pulsé électronique dans la réalisation des photopiles silicium implantées phosphore. Les défauts induits ont été analysés sur la base d'observations en microscopie électronique, en D.L.T.S. et d'étude de dégradation de diodes Schottky. On définit une méthode permettant d'améliorer notablement les valeurs de $V_{o c}$ en associant des électrons de faible énergie cinétique moyenne $(10 \mathrm{keV})$, des fluences faibles $\left(\leq 1 \mathrm{~J} / \mathrm{cm}^{2}\right)$ sur cibles portées à $450^{\circ} \mathrm{C}$. Des valeurs de $\mathrm{V}_{\text {oc }}$ comparables à celles obtenues par recuit thermique conventionnel sont observées.

\section{ABSTRACT}

Defects associated to pulsed electron beam annealing of $P$ implanted Si solar cells lead to poor $V_{\text {oc }}(<500 \mathrm{mV})$. Their nature is discussed on the basic of S.E.M. observations, D.L.T.S. study and degradation of electrical characteristics of Schottky barriers. An improved. PEBA process is determined, characterized by a low mean energy electron beam (10 keV) associated to a starting temperature of $450^{\circ} \mathrm{C}$ and low fluences $\left(\leq 1 \mathrm{~J} / \mathrm{cm}^{2}\right)$. Values of $\mathrm{V}$ oc similar to conventional thermal annealing are obtained.

\section{INTRODUCTION}

Solar cells made by Pulsed Electron Beam Annealing (PEBA) of phosphorous implanted silicon are characterized by a very good short-circuit current and a rather poor open-circuit voltage $\mathrm{v}_{\text {oc }} / 1,2 /$. As for laser annealing a significative improvement (typically $40 \mathrm{mV}$ ) is obtained with a post thermal treatment at $\mathrm{T} \simeq 400^{\circ} \mathrm{C}$.

In this work effects of heating the samples during the pulse are investigated. In addition an optimization of the PEBA process is determined.

\section{PEBA SOLAR CELLS}

$\left(N_{A}=10^{16} \mathrm{~cm}^{-3}\right)$. In order to give some basis for the PEBA treatment optimization, the results of two different solar cells processes are compared in this section.

$\mathrm{n}^{0} 1: \mathrm{p}^{+}$annealed with a $10 \mathrm{keV}$ mean energy electron beam pulse $/ 1,3 /$

$\mathrm{n}^{\circ} 2$ : $\mathrm{p}^{+}$annealed with a higher mean electron energy $(15 \mathrm{keV})$, leading to a more penetrating dose profile $/ 2 /$. 
Details about the PEBA process are also given in ref./2/. In both cases, the pulse duration was about $50 \mathrm{~ns}$ and fluences were in the range $0.8-1.2 \mathrm{~J} / \mathrm{cm}^{2}$.

A computer simulation of PEBA induced thermal effects have been performed $/ 4 /$ in order to investigate the particular features of the melting and freezing kinetics as a function of the substrate starting temperature.

For process $n^{\circ} 1$ at $20^{\circ} \mathrm{C}$ crystalline silicon is fully molten over 0.35 micron with only $1 \mathrm{~J} / \mathrm{cm}^{2}$. For process $\mathrm{n}^{\circ} 2$ with $1.2 \mathrm{~J} / \mathrm{cm}^{2}$ the enthalpy required for complete melting of crystalline silicon is not reached and an inhomogeneous physical state is obtained in the melting layer.

The amorphous front layer $(0.2 \mathrm{micron})$ is fully molten while a "melt like" state is achieved in the underlying crystal up to 0.65 micron. So annealing at $1 \mathrm{~J} / \mathrm{cm}^{2}$ is more effective with process $n^{\circ} 1$ than with process $n^{\circ} 2$.

Moreover, the effect of heating silicon before PEBA consists essentially in an increase of the induced melting layer thickness for a given fluence and in a smaller thermal gradient in the solid leading to a longer freezing kinetic. With a $450^{\circ} \mathrm{C}$ starting temperature the same melting depths as at $20^{\circ} \mathrm{C}$ are obtained with only $0.85 \mathrm{~J} / \mathrm{cm}^{2}$ for the process $n^{\circ} 1$ and $1 \mathrm{~J} / \mathrm{cm}^{2}$ for the process $\mathrm{n}^{\circ} 2$ respectively.

Excellent annealing is obtained with process $n^{\circ} 1$ at only $0.8 \mathrm{~J} / \mathrm{cm}^{2}$ and with process $\mathrm{n}^{\circ} 2$ at $1.2 \mathrm{~J} / \mathrm{cm}^{2}$ The junction depth is less than $200 \mathrm{~nm}$ with a $\mathrm{N}^{+}$layer dopant concentration higher than $10 \% / \mathrm{cm}^{3}$. Solar cells were realized with PEBA wafers according the following process.

$\mathrm{Ti}-\mathrm{Pd}-\mathrm{Ag}$ grid contacts were then evaporated and a $80 \mathrm{~nm}$ thick $\mathrm{TiO}_{2}$ A.R. coating was deposited at $325^{\circ} \mathrm{C}$. The transparency of the grid was $94.5 \%$. An aluminium layer was deposited on the back side of the wafers and annealed during $20 \mathrm{mn}$ at $450^{\circ} \mathrm{C}$. Assuming a uniform junction model the expected short circuit current $I_{s c}$ and $V_{o c}$ for our starting material are respectively $33 \mathrm{~mA} / \mathrm{cm}^{2}$ and $580 \mathrm{mV}$ (AM1). The best experimental value obtained for I $\mathrm{sc}$ was $32.4 \mathrm{~mA} / \mathrm{cm}^{2}$. This value agrees with the theorical one and with the spectral response shown on Fig.1 which is consistent with a base minority carrier diffusion length of 100 microns. So the overall process does not affect the starting material properties. Values of $v_{\text {oc }}$ are plotted on table 1 and compared to values obtained with process $n^{\circ} 1$.

\begin{tabular}{|l|c|cc|cc|cc|}
\hline Annealing & $\begin{array}{c}\text { Thermal } \\
850^{\circ} \mathrm{C} 15 \mathrm{mn}\end{array}$ & $\begin{array}{l}450^{\circ} \mathrm{C} 10 \mathrm{mn} \\
\operatorname{PEBA}\left(20^{\circ} \mathrm{C}\right)\end{array}$ & PEBA $20^{\circ} \mathrm{C}$ & $\begin{array}{l}450^{\circ} \mathrm{C} \quad 10 \\
+\operatorname{PEBA}\left(450^{\circ} \mathrm{C}\right)\end{array}$ \\
\hline Process $\mathrm{n}^{\circ}$ & Reference & 1 & 2 & 1 & 2 & 1 & 2 \\
\hline $\mathrm{V}_{\text {oc }}(\mathrm{mV})$ & 562 & 500 & 480 & 545 & 518 & 558 & 528 \\
\hline
\end{tabular}

Table 1 - Open circuit voltage of $\mathrm{P}$ implanted $\mathrm{Si}$ versus PEBA process

Two important features appear. First the process $n^{\circ} 1$ gives the best value in all cases. Secondly PEBA at $450^{\circ} \mathrm{C}$ leads to $558 \mathrm{mV}$ wich is yet $20 \mathrm{mV}$ below the theoretical value but is very similar to the reference. So a first conclusion is that an optimized PEBA process gives very good results compared to the conventional thermal process. 


\section{DISCUSSION}

As other pulsed annealing technics PEBA induces defects in silicon. In a recent paper a thorough study of extended defect were performed by mean of electron microscopy $/ 5 /$. Comparison made between conventional thermal annealing and PEBA have shown that the latter removes defects associated with thermal annealing. However observations has revealed the existence of dislocations and subgrain boundaries with a fluence increasing density. Polygonization seems to indicate that climb as well as glide are active in the dislocation mobility. Fig. 2 shows the S.E.M. micrograph of a bevelled sample pulsed with $1.2 \mathrm{~J} / \mathrm{cm}^{2}$ at $20^{\circ} \mathrm{C}$ with the $15 \mathrm{keV}$ mean energy electron beam pulse. One remarks first the array of dislocation emergence as previously described $/ 5 /$. Secondly, the extent of the dislocated zone nearly

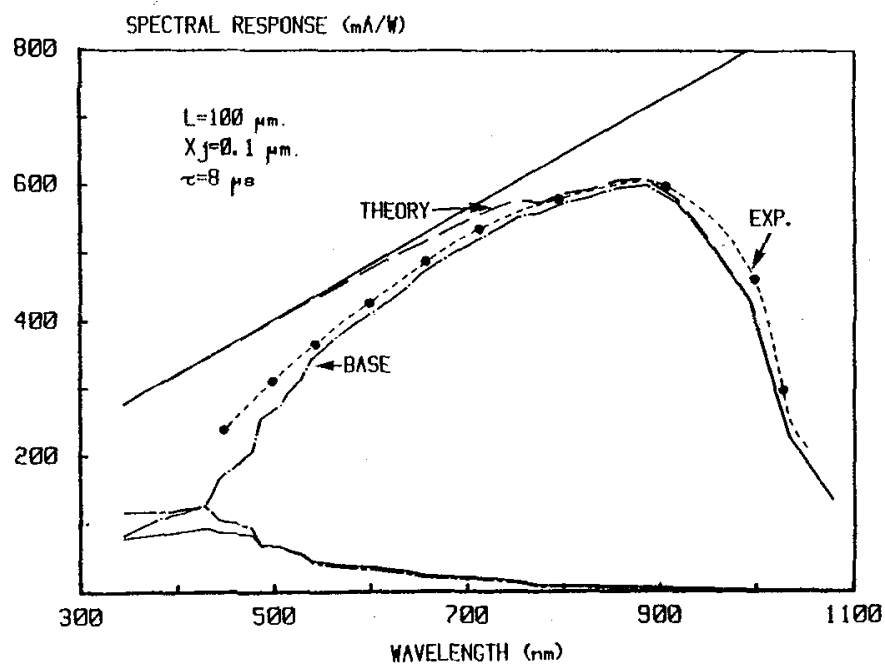

Fig. 1 - Spectral response of PEBA Si solar cell.

coincide with the melting zone thickness as calculated in sec.2. At $450^{\circ} \mathrm{C}$ no extended defects appear on samples treated up to $0.9 \mathrm{~J} / \mathrm{cm}^{2}$. This can be related to the smaller thermal gradients and longer freezing kinetics in that case.

In the other hand quenched-in point defects are associated to pulsed annealing $/ 6,7 /$. In a previous work /7/ deep level transient spectroscopy (DLTS) performed with Schottky diodes made on PEBA processed P-type virgin silicon revealed typical defects associated to PEBA depending on the irradiation characteristics.

In this work, we have performed DLTS study on $\mathrm{p}^{+} / \mathrm{n}$ junction made as the above discussed solar cells ( $n^{\circ} 2$ process). A typical spectrum is shown on Fig.3. Two discrete hole trap levels appear $C_{1}(=0.22 \mathrm{eV})$ and $C_{3}(=0.48 \mathrm{eV})$ for which the biasing conditions correspond to an analyzed surface layer thickness of about 0.6 micron. The capture cross sections are respectively $3.10^{-15} \mathrm{~cm}^{-2}$ and $10^{-14} \mathrm{~cm}^{-2}$. The broad structure $C_{2}$ partially superimposed to the peak $\mathrm{C}_{3}$ is likely to be due to a band of levels. The hole trap levels observed cannot be assigned to already known defect in Si.

Finally, in order to obtain informations about the effect of PEBA alone on the silicon surface degradation we have studied the electrical properties of Schottky barrier made 
on virgin silicon after irradiation at $1.2 \mathrm{~J} / \mathrm{cm}^{2}$ with a $15 \mathrm{keV}$ mean energy electron beam pulse. The results are shown on table 2. One can observe a strong degradation of the diodes after PEBA at $20^{\circ} \mathrm{C}$. A post thermal treatment is not sufficient to completely recover the reference diode characteristics. An improvement is observed for the $450^{\circ} \mathrm{C}$ PEBA processed samples. However defects are always present as evidenced by the large value of the saturation current.

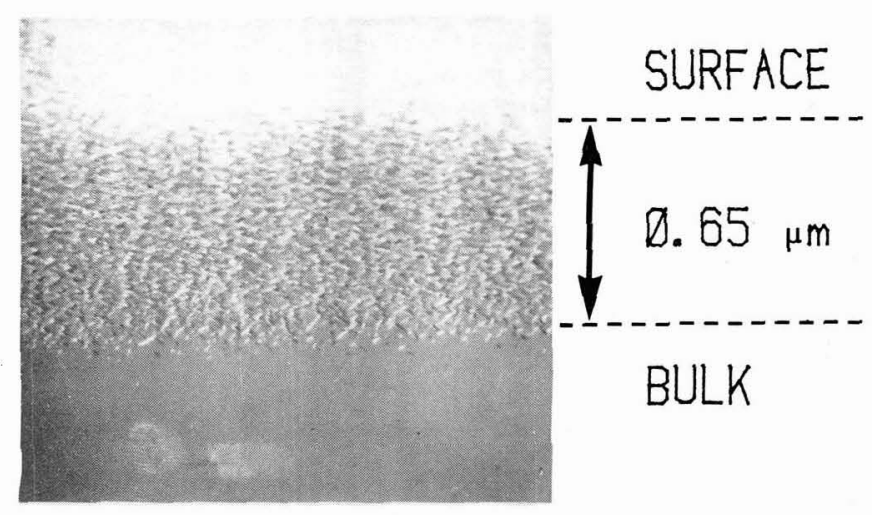

Fig. 2 - Scanning electron microscopy on bevelled sample of PEBA silicon. Dislocation emergence in whole the melting zone.

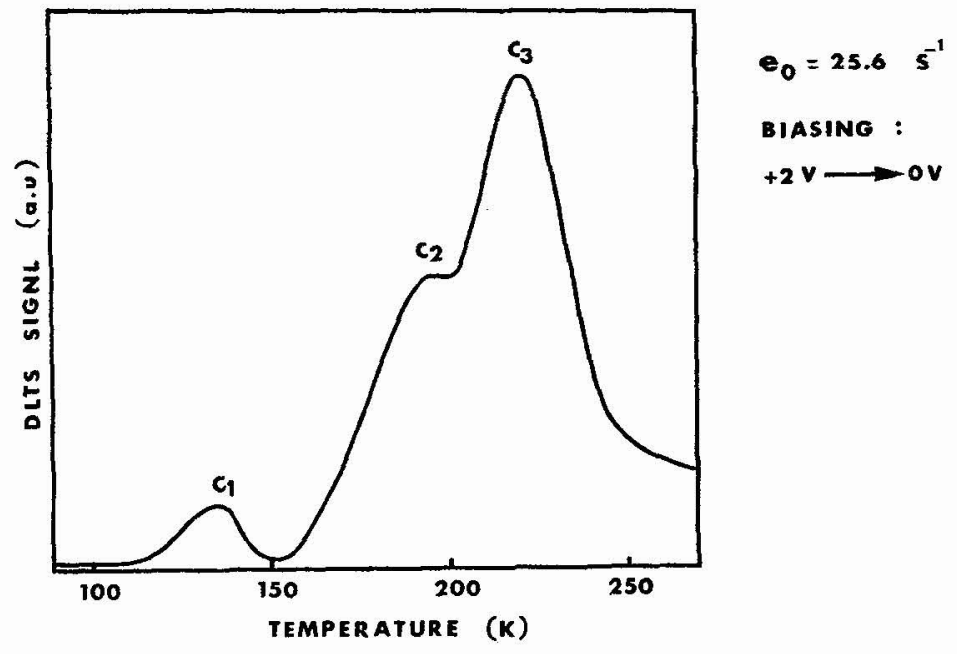

Fig. 3 - DLTS spectrum for $\mathrm{Si}^{+} \mathrm{n}$ diode. 


\begin{tabular}{|l|c|c|c|c|c|}
\hline & $\begin{array}{l}\text { Sample } \\
\text { Temperature }\end{array}$ & $\mathrm{n}$ & $\mathrm{I}_{\mathrm{s}}\left(\mathrm{A} / \mathrm{cm}^{2}\right)$ & $\mathrm{C}(\mathrm{pF})$ & $\mathrm{V}_{\mathrm{Bn}}(\mathrm{V})$ \\
\hline $\mathrm{PEBA}$ & $20^{\circ} \mathrm{C}$ & 2.90 & $3.3510^{-3}$ & 165.2 & 0.570 \\
\hline $\begin{array}{l}\mathrm{PEBA} \\
+450^{\circ} \mathrm{C} 30 \mathrm{mn}\end{array}$ & $20^{\circ} \mathrm{C}$ & 1.96 & $1.0310^{-3}$ & 124.2 & 0.600 \\
\hline $\mathrm{PEBA}$ & $450^{\circ} \mathrm{C}$ & 1.78 & $4.5110^{-4}$ & 110.4 & 0.621 \\
\hline Reference & & 1.16 & $6.6010^{-7}$ & 89.7 & 0.791 \\
\hline
\end{tabular}

Table 2 - Evolution of Schottky barrier characteristics made on PEBA processed Si surface $\left(1.2 \mathrm{~J} / \mathrm{cm}^{2}\right) \mathrm{n}$ : ideality factor $; \mathrm{I}_{\mathrm{s}}$ : saturation current ; $\mathrm{C}$ : capacitance at $-1 \mathrm{~V}$ at $1 \mathrm{MHz} ; \mathrm{V}_{\mathrm{Bn}}$ :
barrier height.

\section{CONCLUSION}

Patel et al $/ 8 /$ have shown that dislocations could be annealed only at temperatures higher than $700^{\circ} \mathrm{C}$. So the residual Schottky diode degradation and for the solar cells the value of $\mathrm{V}_{\mathrm{OC}}$ after PEBA at $450^{\circ} \mathrm{C}$ could be related to dislocations. The poor value of $\mathrm{V}_{\text {oc }}$ after PEBA at $20^{\circ} \mathrm{C}$ could be related to a high concentration of quenched-in point defects.

The lower quenching rate induced by PEBA on silicon heated up to $450^{\circ} \mathrm{C}$ is likely to reduce the point defect generation mechanism and to improve the value of $\mathrm{V}_{\text {oc }}{ }^{\circ}$. An improved PEBA treatment of phosphorous implanted Si solar cells is determined by using a low mean energy electron beam $(10 \mathrm{keV})$ associated to a sample temperature of $450^{\circ} \mathrm{C}$. Then a fluence below $1 \mathrm{~J} / \mathrm{cm}^{2}$ is convenient and values of $v_{o c}$ similar to conventional thermal annealing are obtained.

\section{ACKNOWLEDGEMENT}

This work was supported by A.F.M.E. and by C.N.R.S. (PIRSEM).

\section{BIBLIOGRAPHY}

/1/ GREENWẢLD A.C., KIRKPATRICK A.R., LITTLE R.G., MINNUCCI J.A., J.Appl. Phys. SO, 2 (1979) 783

12/ LAUGIER A., BARBIER D., CHEMISKY G., Proc. 4th E.C. Photovoltaic Solar Energy Conf. Reidel edit. (1982) 1007

13/ GREENWALD A.C. Private Communication

14/ CHEMISKY G., BARBIER D., LAUGIER A., this conference

15/ THOLOMIER M., PITAVAL M., AMBRI M., BARBIER D., LAUGIER A., J.Appl.Phys. 53 (1983) 1588

16/ ChANTRE A., KECHOUANE M., BOIS D., Laser and Electron Beam Processing of Materials, M.R.S. Proc.Acad.Press (1981) 385

17/ BARBIER D., KECHOUANE M., CHANTRE A., LAUGIER A., Laser-Solid Interactions and Transient Thermal Processing of Materials. M.R.S. Proc. Elsevier (1982) to be published

18/ PATEL J.R., KIMMERLING L.C., J.Phys. C6, $\underline{40}$ (1979) 67 